\title{
The influence of organizational culture, principal leadership, and teacher work motivation on teacher performance
}

\author{
Indra Hasan ${ }^{1}$, Happy Fitria ${ }^{2}$, Achmad Wahidy $^{3}$ \\ ${ }^{1}$ SMA Negeri 1 Air Sugihan \\ ${ }^{2}$ Universitas PGRI Palembang
}

\begin{tabular}{l} 
Article Info \\
\hline Article history: \\
Received Jul $16^{\text {th }}, 2021$ \\
Revised Aug $14^{\text {th }}, 2021$ \\
Accepted Aug $30^{\text {th }}, 2021$ \\
\hline
\end{tabular}

\section{Keyword:}

Organizational culture

Leadership

Work motivation

Performance

\begin{abstract}
This research aims to describe the influence of organizational culture, principal leadership, and teacher work motivation on teacher performance in SMAN 1 Air Sugihan. The method used is a quantitative research method with a population as well as a sample of 33 people. The data collection techniques used were questionnaires and observations. The data analysis used descriptive analysis, simple regression, and multiple regression with the help of the IBM SPSS version 25,0 Program. The results showed that; (1) there is a positive and significant influence between organizational culture on teacher performance, (2) there is a positive and significant influence between principal leadership on teacher performance, (3) there is an influence which is positive and significant between teacher work motivation on teacher performance, and (4) there is a positive and significant influence between organizational culture, principal leadership, and teacher work motivation on teacher performance.
\end{abstract}

(C) 2021 The Authors. Published by IICET.

This is an open access article under the CC BY-NC-SA license (https://creativecommons.org/licenses/by-nc-sa/4.0

\section{Corresponding Author:}

Indra Hasan

SMA Negeri 1 Air Sugihan

Email: indrahasan29@gmail.com

\section{Introduction}

Superior human resources are the main requirements for the creation of a developed nation and country. The main asset for creating superior Human Resources is education. One of the educational institutions is school. As an institution, the school has a vision, mission, goals, and functions. To do this, schools need professional staff, organizational work procedures, and supporting resources, both financial and non-financial.

The goals of education in schools will be successful if you have Human Resources, including school principals, teachers, students, administrative staff, and other education personnel who can manage the school organization. School management by school members will form a habit in an organization called organizational culture. The Organizational culture that grows and develops in schools will affect the performance of organizational members in it, one of which is the performance of teachers in carrying out their duties.

A pleasant organizational culture has consequences for teachers in carrying out their duties and can lead to good teacher work motivation as well. [1] organizational culture is a set of shared values, principles, traditions, and ways of working that influence the behavior and actions of organizational members. [2] defines that organizational culture is a habit that has lasted a long time and is used and applied in the life of work activities as a driving force to improve the quality of work of employees. The values shared in a school organization will develop along with the times. 
To create an organizational culture that supports the implementation of the organization as a whole, a leader is needed. Leaders in their leadership will provide guidance, determine direction and goals, and create a conducive organizational culture. Therefore, leadership is an important factor to move other people to run an organization.

School is an educational organization led by a principal. [3] the principal is a functional teacher who is given the task of leading a school where a teaching and learning process is held or a place where there is interaction between the teacher who gives lessons and students who receive lessons.

The success or failure of the education and learning process in schools is influenced by the ability of the principal in managing each component of the school. The ability of the principal is of course related to knowledge and understanding of management and leadership, as well as the tasks assigned to him. It is not uncommon for the failure of the education and learning process in schools to be caused by the principal's lack of understanding of the tasks that must be carried out. This shows that the success or failure of a school in achieving its goals and realizing its vision and mission lies in the management and leadership of the school principal [4].

In the process of enhancing teacher performance, one of the principal's responsibilities is as a motivating teacher to streamline the learning process and direct students to future achievement. Strong encouragement from the principal plays an important role for teachers in carrying out their roles such that the success of the teacher is supposed to change for the better with the encouragement of the principal.

"Motivation is a process that starts with a psychological deficiency or needs a drive that is aimed at a goal or incentive" [5]. Motivation as a state within a person that encourages the individual's desire to carry out certain activities to achieve goals [6].

A teacher can work professionally if he has high motivation. Teachers who have high motivation will usually carry out their duties with enthusiasm because there are certain motives or goals behind these actions. This motive is the driving factor that gives him strength so that he is willing and willing to work hard. Work motivation is one of the factors that determine the level of performance of a teacher. Without work motivation, skills, or work effort from a teacher will not improve their performance.

Based on preliminary observations made by researchers at SMA Negeri 1 Air Sugihan with 33 teachers, it appears that there are still teachers whose performance is still low. This can be seen from various phenomena in the field. In making teacher administration, there are still teachers who make and collect it not according to the predetermined time. Some do not make learning tools unless there is an examination. Some use existing learning tools by changing the year and cover. There are those whose presence in teaching does not reach the target as stated in the curriculum because they arrive late, do not enter because of business, do not enter because they are too busy chatting in the office or other place, do not enter because of illness, do not enter because of family matters, do not carry out the full assessment, do not carry out remedial and enrichment programs, and so on.

Furthermore, there are also teachers who are less creative in creating an active and fun learning atmosphere so that in learning activities in the classroom students are not serious and lose their motivation to learn. For example, there are those who only provide notes to students and do not attend class. The use of props is still lacking, even not using props at all. Even though the use of teaching aids or learning media can increase students' enthusiasm for learning.

The existence of the principal as a leader also has an effect. When the principal is absent, there are teachers who leave the classroom and tell stories in the office or in the canteen while their students are noisy and not studying. In addition, there are still teachers who are dissatisfied with school organizational policies and feel that organizational culture does not support teacher self-development. This situation is allowed to continue to develop and affect the success of the teacher's task as a whole.

A good organization will be reflected in the culture or good behavior of the members of the organization which will ultimately lead to the achievement of the goals that the organization has set together [7]. The attitude and behavior of individuals who are not good enough will form an opinion in the work environment that can damage the achievement of organizational goals. Such an opinion will certainly affect teacher performance to be less good. Work according to his wishes without paying attention to the rules or policies that have been agreed upon, come to school and return from school as he wishes, enter teaching often not on time, and do not care about his peers. Completion of tasks not on target for various reasons so that the work being done is neglected. 
Of the several problems encountered, it is important for researchers to carry out further research on teacher performance. Teacher performance in this case is influenced by organizational culture, principal leadership, and teacher work motivation. Therefore, the researcher took the title "The Influence of Organizational Culture, Principal Leadership, and Work Motivation on Teacher Performance in SMA Negeri 1 Air Sugihan". The purpose of this study is to describe the influence of organizational culture, principal leadership, and teacher work motivation on teacher performance at SMA Negeri 1 Air Sugihan.

\section{Method}

This research was conducted at SMA Negeri 1 Air Sugihan using quantitative research methods. [8] the quantitative research method is to see the effect partially between the existing variables. The variable is from the property or value of values of people, the organization, or the activities that can be a variety of some species that are sought by researchers to study and then draw conclusions. The variables in quantitative research consist of $3 \mathrm{X}$ variables, namely organizational culture (X1), principal leadership (X2), and teacher work motivation (X3), and Y variable, namely teacher performance. The purpose of this study is to describe the influence of organizational culture, principal leadership, and teacher work motivation on teacher performance at SMA Negeri 1 Air Sugihan.

The population in the study amounted to 33 teachers. In order to obtain a representative sample, the sampling technique uses saturated sampling technique, where all members of the population are members of the sample. The data collection technique used was a questionnaire. Apart from questionnaires, data collection was assisted by observation. The time research was carried out in September - October 2020.

The instrument in this study used a closed questionnaire, namely a questionnaire that had provided an alternative answer so that the respondents just had to choose. Statements that are structured as instruments in the form of positive statements using a measurement scale, namely the Likert scale with 4 alternative answers. The reason for using these 4 alternative answers is to avoid answers that tend to be in the middle value.

To measure organizational culture variables taken from the opinion of Stephen P. Robbins, namely individual initiative, tolerance for risk, direction, integration, management support, supervision, identity, reward systems, tolerance to conflict, and communication patterns. Furthermore, the principal leadership variable is measured based on the role and function of the principal, among others, as educators, as managers, as administrators, as supervisors, as leaders, as innovators, and as motivators. Then, the variable of teacher work motivation is measured from two dimensions, namely internal motivation and external motivation.

Meanwhile, to measure teacher performance variables refers to teacher performance appraisals made by the Ministry of National Education, namely planning, implementing, and evaluating (assessing) learning activities.

Before the research questionnaire was used to obtain data, content validity was first carried out, then tested to see the validity and reliability of the questionnaire so that it could be used as a data collection tool. Furthermore, to determine the statistics to be used, if the data is normally distributed and homogeneous, then parametric statistics are used and vice versa if the data is not normal and not homogeneous then nonparametric statistics are used. Before the data is further analyzed using multiple regression analysis, first tested the normality of the data distribution, the influence linearity test, the heteroskedasticity test (homogeneity test), and the multicollinearity test to test the independence of the independent variables.

The data analysis used descriptive analysis, simple regression, and multiple regression with the help of the IBM SPSS version 25,0 Program.

\section{Results and Discussions}

\section{The The Influence of Organizational Culture on Teacher Performance}

Based on the respondents' responses to the organizational culture variable, it shows that the total score for the organizational culture variable is 103.06 , the maximum score is 119.00 and the minimum score is 90.00 and the standard deviation is 5.974. The distribution of the total score that was below the average was 16 respondents (48.5\%), while those who were at the average score and above were 17 respondents (51.5\%). When viewed from the histogram image shows that the data on the concentration of organizational culture variables is leaning to the right. This indicates that the organizational culture is in the medium to high category. Thus, the organizational culture that is applied today can still be improved or maintained the current state. 
Before the regression analysis was carried out, the research data was processed using the computer assistance of the IBM SPSS version 25.0 program to be tested first with the results: the data is normally distributed, linear, there is no heteroscedasticity problem, and there are no multicollinearity symptoms so that it can be continued to the linear regression analysis stage simple.

After performing a simple linear regression analysis test with the help of a computer program IBM SPSS version 25.0, the tcount $=7.065$, while the ttable value for the $5 \%$ significance level with degrees of freedom $(\mathrm{df})=\mathrm{n}-\mathrm{k}=33-2=31$ two-sided test so that the value of ttable $=2.039$. Because tcount is greater than ttable (7,065> 2,039), the hypothesis which states "there is a significant influence between organizational culture on teacher performance at SMA Negeri 1 Air Sugihan" is accepted with positive and significant results. The contribution of organizational culture variables to teacher performance can be seen from the value of $\mathrm{R}=$ 0.785 and the coefficient of determination $=0.617$. This means that the teacher's performance is influenced by $61.7 \%$ by organizational culture, the remaining $38.3 \%$ is influenced by other variables or other factors.

These results are following the situation in the field through the researchers' observations. Based on these observations, it shows that the organizational culture developed in SMA Negeri 1 Air Sugihan is good. This can be seen from the maintenance of good kinship between fellow teachers and other school members both inside and outside the school environment which is shown through school family social gathering activities, the friendship between school members during religious holidays, weddings, thanksgiving, visiting the sick, and when a school member dies. In addition, every teacher always implements the 5S culture (smile, greetings, greetings, courtesy, and courtesy), both fellow teachers and other school members as well as when receiving from outside those who come to school, as well as the culture of always keeping the school environment clean for all residents. school.

The results of the research that have been done indicate that there is a positive and significant influence between organizational culture and teacher performance. High organizational culture will provide a strong impetus for teachers to work well which will result in maximum performance. On the other hand, a low organizational culture causes teachers to be less enthusiastic at work which will cause work results to be less than optimal. This is according to the opinion of that a good organizational culture will create optimal performance, such as performance, which is a record of output on a certain work function or activity over a certain period of time [9].

The results of this study are also in line with research conducted [10] which shows that organizational culture has a positive direct effect on teacher performance. Organizational culture is an invisible social force that can move people in an organization to carry out work activities [11]. With good organizational culture, teachers will be responsible for their work and can complete it effectively and efficiently.

In terms of performance, the role of organizational culture is very important in improving teacher performance. Many studies of organizational culture affect productivity, performance, commitment, confidence, and ethical behavior. States that organizational culture has a significant impact on long-term organizational performance. This means that for a teacher an understanding of organizational culture will make it easier to solve problems in teaching so that it can make a good contribution to their performance [12].

A strong culture is also said to help performance because it provides the necessary structure and control without having to rely on stifling formal bureaucracies that can suppress the growth of motivation and innovation [13]. This means that building a good organizational culture will have a positive impact on teacher performance and can improve teacher performance.

\section{The Influence of Principal Leadership on Teacher Performance}

Based on the respondents' responses to the principal's leadership variable, it shows the total score of the principal's leadership variable, the mean value is 105.91 , the maximum score is 118.00 and the minimum score is 91.00 with a standard deviation of 5.222. The distribution of the total scores that are below the average is as many as 7 respondents $(21.2 \%)$, who are in the total score - average and above - average, as many as 26 respondents $(78.8 \%)$. When viewed from the histogram image shows that the data on the concentration of organizational culture variables is leaning to the right. This indicates that the principal's leadership is in the medium to high category. Thus, the current leadership of the principal is good and can still be improved or maintain the current situation.

Before the regression analysis was carried out, the research data was tested first with the help of the IBM SPSS Version 25.0 computer program with the results of the data being normally distributed, linear, there was 
no heteroscedasticity problem, and there were no symptoms of multicollinearity so that it could be continued to the simple linear regression analysis stage.

After fulfilling the requirements, the simple linear regression analysis test was processed with the help of the IBM SPSS version 25.0 computer program so that the tcount $=8.311$, while the ttable value for the $5 \%$ significance level with degrees of freedom $(\mathrm{df})=(\mathrm{n})-(\mathrm{k})=33-2=31$ and the test was carried out in two sides so that the value of ttable $=2.039$. Because tcount is greater than $t$ table $(8.311>2.039)$, the hypothesis which states "there is a significant influence between principal leadership on teacher performance at SMA Negeri 1 Air Sugihan" is accepted with positive and significant results. The contribution of the principal's leadership variable to teacher performance can be seen from the value of $\mathrm{R}=0.831$ and the coefficient of determination $=$ 0.690 . This means that $69 \%$ of teacher performance is influenced by the principal's leadership, the remaining $31 \%$ is influenced by other variables or other factors.

These results are following the situation in the field through the researchers' observations. Based on these observations, it shows that the leadership of the principal applied in SMA Negeri 1 Air Sugihan is good. This condition can be seen from the figure of the principal who is used as a role model for teachers, such as the actions of the principal who always provides inspiration and motivation to his subordinates to continue to excel to the maximum, gives awards directly to each outstanding teacher, and provides regular guidance to each teacher continues to work on improving its performance.

The principal has a heavy-duty, role, and responsibility as a leader in his school concerning human resource management, namely the teachers he leads. This means that if the principal's leadership is good, the teacher's performance will increase. This result is following the theory or opinion of [14] which states that professional school principals in the new paradigm of educational management will have a positive impact and quite fundamental changes in reforming the education system in schools.

These results are following the situation in the field through the researchers' observations. Based on these observations, it shows that the leadership of the principal applied in SMA Negeri 1 Air Sugihan is good. This condition can be seen from the figure of the principal who is used as a role model for teachers, such as the actions of the principal who always provides inspiration and motivation to his subordinates to continue to excel to the maximum, gives awards directly to each outstanding teacher, and provides regular guidance to each teacher continues to work on improving its performance.

\section{The Effect of Teacher Work Motivation on Teacher Performance}

Based on the responses of respondents to the teacher work motivation variable, it shows that the total score of the teacher's work motivation variable is 105.55 , the maximum score is 116.00 and the minimum score is 90.00 with a standard deviation of 4.658 . The distribution of the total score that is below the average is 6 respondents (18.2\%), who are in the total score - average and above the average - obtained by 27 respondents $(81.8 \%)$. When viewed from the histogram image shows that the data centering of the teacher work motivation variable is leaning to the right. This indicates that the teacher's work motivation is in the medium to high category. Thus, the teacher's work motivation that is currently applied is good and can still be maximally improved or maintain the current state.

Before the regression analysis was carried out, the research data was tested first with the help of the IBM SPSS version 25.0 computer program with the results of the data being normally distributed, linear, there was no heteroscedasticity problem, and there were no symptoms of multicollinearity so that it could be continued to the simple linear regression analysis stage.

After fulfilling the requirements, the simple linear regression analysis test was processed with the help of the IBM SPSS version 25.0 computer program so that the tcount $=10.286$, while the $t$-table value for the $5 \%$ significance level with degrees of freedom $(\mathrm{df})=(\mathrm{n})-(\mathrm{k})=33-2=31$ and the test was carried out in two sides so that the value of $t$ table $=2.039$. Because $t$ count is greater than $t$ table $(10.286>2.039)$, the hypothesis which states "there is a significant influence between teacher work motivation on teacher performance at SMA Negeri 1 Air Sugihan" is accepted with positive and significant results. The variable contribution of teacher work motivation to teacher performance can be seen from the value of $\mathrm{R}=0.879$ and the coefficient of determination $=0.773$. This means that the teacher's performance is influenced by $77.3 \%$ by teacher work motivation, while the remaining $22.7 \%$ is influenced by other variables or other factors.

These results are following the situation in the field through the researchers' observations. Based on these observations, it shows that the teacher's work motivation is good. This can be seen from the enthusiasm and responsibility of the teachers of SMA Negeri 1 Air Sugihan in carrying out online learning activities (online) 
during the COVID 19 pandemic. Starting from preparation, implementation, evaluation, or assessment. Even though it is currently in a pandemic state of COVID 19, the implementation of online learning activities is still ongoing. Most of the teachers carry out online learning from school, some from home. The condition of the COVID 19 pandemic has motivated teachers to be able to use information technology in online learning activities.

The results of this study agree with which states that work motivation is one of the factors that determine a person's performance [15]. The influence of motivation on a person's performance depends on how much motivation intensity is given. Teacher work motivation is nothing but a process carried out to mobilize teachers so that their behavior can be directed at real efforts to achieve predetermined goals.

Giving teacher work motivation can be in the form of monitoring teacher performance appraisals so that teachers who have good abilities can be given promotions. Besides, it can be through the provision of rewards or incentives, pleasant working conditions, providing opportunities for advancement, and a harmonious working relationship. The increase in teacher work motivation can have an impact on optimal teacher performance.

The results of research that have been done also show that there is a positive and significant influence between teacher work motivation and teacher performance. This means that the work motivation variable can contribute to the performance of teachers in SMA Negeri 1 Air Sugihan. Therefore, the increase in teacher performance, the work motivation needs to be improved again.

\section{The Influence of Organizational Culture, Principal Leadership, and Teacher Work Motivation on Teacher Performance}

Before the regression analysis was carried out, the research data was tested first with the help of the IBM SPSS version 25.0 computer program with the results: the data were normally distributed, linear in nature, there was no heteroscedasticity problem, and there were no symptoms of multicollinearity so that it could be continued to the multiple linear regression analysis stages.

After fulfilling the requirements, the multiple linear regression analysis tests was processed with the help of the IBM SPSS version 25.0 computer program so that the calculated Fcount $=33.659$, while the Ftable value for the significance level or $5 \%$ probability $=2.93$. Because Fcount $>$ Ftable, simultaneously the variables of organizational culture, principal leadership, and teacher work motivation have a positive and significant effect on teacher performance. Thus, the hypothesis which states that "there is a significant influence between organizational culture, principal leadership, and teacher work motivation on teacher performance at SMA Negeri 1 Air Sugihan" is accepted.

The value of the simultaneous contribution of organizational culture variables, principal leadership, and teacher work motivation to teacher performance can be seen from the value of $R=0.881$, and the coefficient of determination $=0.777$. This means that the teacher's performance is affected simultaneously by $77.7 \%$ by organizational culture, principal leadership, and teacher work motivation, while the remaining $22.3 \%$ is influenced by other variables or other factors.

\section{Conclusions}

Based on the results of research and discussion, it can be concluded that there is a positive and significant influence between organizational culture, principal leadership, and teacher work motivation on teacher performance at SMA Negeri 1 Air Sugihan..

\section{References}

Robbins, Stephen P, dan Coulter Mary. (2010). Manajemen (Terjemahan). Jakarta: Erlangga.

Fahmi, I. (2014). Perilaku Organisasi : Teori, Aplikasi, dan Kasus. Bandung: Alfabeta.

Wahjosumidjo. (2010). Kepemimpinan Kepala Sekolah Tinjauan Teoritik dan Permasalahannya. Jakarta: PT Raja Grafindo Persada

Mulyasa, E. (2017). Manajemen dan Kepemimpinan Kepala Sekolah. Jakarta: Bumi Aksara.

Luthans, Fred. (2002). Perilaku Organisasi (Terjemahan). Yogyakarta: ANDI.

Handoko, T. Hani. (2003). Manajemen. Yogyakarta: BPFE Yogyakarta. 
Arifin, Miftahul. (2018). Pengaruh Budaya Organisasi, Kepemimpinan Kepala Sekolah, dan Motivasi Terhadap Tenaga Pendidik di SMPN 2 Paciran. Tesis. Program Pascasarjana UIN Sunan Ampel Surabaya. Tersedia pada :http://digilib.uinsby.ac.id/id/eprint/28328 Diakses tanggal 5 Juni 2020.

Sugiyono. (2019). Metode Penelitian Pendidikan (Kuantitatif, Kualitatif, dan R\&D). Bandung: Alfabeta.

Bernardin, H., and John, H. (2017). Human Resources Management, An Experiental Approach. Jakarta: Gramedia Pustaka.

Fitria, Happy. (2018). The Influence Of Organizational Culture And Trust Through The Teacher Performance In The Private Secondary School In Palembang. International Journal Of Scientific \& Technology Research Volume 7, Issue 7, July 2018.

Sutrisno, Edy. (2010). Budaya Organisasi. Jakarta: Kencana

Tika, Moh. Pabundu. (2014). Budaya Organisasi dan Peningkatan Kinerja Perusahaan. Jakarta: Bumi Aksara.

Sudarmanto. (2014). Kinerja dan Pengembangan Kompetensi SDM. Yogyakarta: Pustaka pelajar.

Mulyasa, E. (2004). Menjadi Kepala Sekolah Profesional. Bandung: Remaja Rosda Karya.

Uno, Hamzah B. (2013). Teori Motivasi dan pengukurannya: Analisis di Bidang Pendidikan. Jakarta: Bumi Aksara. 